\title{
Effect of polyamines and synthetic polyamine-analogues on the expression of antizyme (AtoC) and its regulatory genes Panagiota S Filippou1 ${ }^{1}$, Efthimia E Lioliou ${ }^{1,5}$, Christos A Panagiotidis ${ }^{2}$, Constantinos $\mathrm{M}$ Athanassopoulos ${ }^{3}$, Thomas Garnelis ${ }^{3}$, Dionyssios Papaioannou ${ }^{3}$ and Dimitrios A Kyriakidis*1,4
} \begin{abstract}
of Pharmaceutical Sciences, Aristotle University of Thessaloniki, Thessaloniki, 54124, Greece, ${ }^{3}$ Laboratory of Synthetic Organic Chemistry, Department of Chemistry, University of Patras, 26500 Patras, Greece, ${ }^{4}$ The National Hellenic Research Foundation 48, Vas. Constantinou Ave 11635, Athens, Greece and 5 Present address: Laboratory of Procaryotic Molecular Genetics, Smurfit Institute of Genetics, Trinity College, Dublin, Ireland

Email: Panagiota S Filippou - filippouyiota@yahoo.gr; Efthimia E Lioliou - efi_lioliou2004@yahoo.ie;

Christos A Panagiotidis - pchristo@pharm.auth.gr; Constantinos M Athanassopoulos - kath@chemistry.upatras.gr;

Thomas Garnelis - thgarnelis@gmail.com; Dionyssios Papaioannou - dapapaio@chemistry.upatras.gr;

Dimitrios A Kyriakidis* - kyr@chem.auth.gr

* Corresponding author
\end{abstract}

Address: ${ }^{1}$ Laboratory of Biochemistry, Department of Chemistry, Aristotle University of Thessaloniki, Thessaloniki, 54124, Greece, ${ }^{2}$ Department

Published: 15 January 2007

BMC Biochemistry 2007, 8:1 doi:10.1 |86/|47|-209|-8-I
Received: 06 October 2006

Accepted: 15 January 2007

This article is available from: http://www.biomedcentral.com/I47I-209|/8/I

(c) 2007 Filippou et al; licensee BioMed Central Ltd.

This is an Open Access article distributed under the terms of the Creative Commons Attribution License (http://creativecommons.org/licenses/by/2.0), which permits unrestricted use, distribution, and reproduction in any medium, provided the original work is properly cited.

\begin{abstract}
Background: In bacteria, the biosynthesis of polyamines is modulated at the level of transcription as well as post-translationally. Antizyme ( $\mathrm{Az})$ has long been identified as a non-competitive protein inhibitor of polyamine biosynthesis in $E$. coli. Az was also revealed to be the product of the ato $C$ gene. Ato $C$ is the response regulator of the AtoS-AtoC two-component system and it functions as the positive transcriptional regulator of the atoDAEB operon genes, encoding enzymes involved in short chain fatty acid metabolism. The antizyme is referred to as AtoC/Az, to indicate its dual function as both a transcriptional and post-translational regulator.

Results: The roles of polyamines on the transcription of atoS and ato $C$ genes as well as that of atoDAEB (ato) operon were studied. Polyamine-mediated induction was tested both in atoSC positive and negative $E$. coli backgrounds by using $\beta$-galactosidase reporter constructs carrying the appropriate promoters patoDAEB, patoS, patoC. In addition, a selection of synthetic polyamine analogues have been synthesized and tested for their effectiveness in inducing the expression of ato $C / A z$, the product of which plays a pivotal role in the feedback inhibition of putrescine biosynthesis and the transcriptional regulation of the ato operon. The effects of these compounds were also determined on the ato operon expression. The polyamine analogues were also tested for their effect on the activity of ornithine decarboxylase (ODC), the key enzyme of polyamine biosynthesis and on the growth of polyamine-deficient $E$. coli.
\end{abstract}

Conclusion: Polyamines, which have been reported to induce the protein levels of AtoC/Az in $E$. coli, act at the transcriptional level, since they cause activation of the ato $C$ transcription. In addition, a series of polyamine analogues were studied on the transcription of ato $C$ gene and ODC activity. 


\section{Background}

Polyamines are indispensable cellular components implicated in many physiological functions, such as DNA replication and repair, transcription, protein synthesis and post-translational protein modifications [1]. Together with magnesium ions, polyamines account for the majority of the intracellular cationic charges $[2,3]$ and they are essential for the normal cell growth and viability of almost all living cells [4,5]. The intracellular polyamine concentrations need to be maintained within relatively narrow limits in order to both ensure optimal cell growth and avoid potential toxic effects arising from the presence of high concentrations of these polycations.

Polyamine homeostasis involves a combination of several sensitive feedback systems regulating their synthesis, degradation and transport [6]. Regulation of polyamine biosynthesis is complex and the key biosynthetic enzyme, ODC is one of the most highly regulated enzymes [7]. The protein levels of ODC and/or its activity are modulated at the transcriptional, translational and post-translational levels [8]. The post-translational regulation of ODC is mainly mediated by polyamine-inducible non-competitive protein inhibitor(s), termed antizymes [9-13]. The mammalian antizyme has also been found to promote the ubiquitin-independent degradation of ODC by the $26 S$ proteasome $[14,15]$, as well as to negatively regulate polyamine transport $[16,17]$.

In Escherichia coli, the biosynthesis of polyamines is modulated both at the level of transcription as well as posttranslationally $[18,19]$. The post-translational regulation of polyamine biosynthesis takes place either directly by feedback inhibition of ODC activity by polyamines [20] or indirectly by polyamine-inducible protein inhibitors $[2,9]$.

The E. coli antizyme (Az) has been identified as a noncompetitive protein inhibitor of ODC, the synthesis of which is induced by polyamines $[9,10]$. The cloning and sequencing of the E. coli Az gene [21] disclosed unexpectedly that Az might also have a second function as the transcriptional regulator of a two-component system (TCS) family [22]. Indeed, it was shown that $\mathrm{Az}$ is identical to the gene product of atoC $[23,24]$, which is a positive transcriptional regulator of the atoDAEB operon genes, encoding enzymes involved in short chain fatty acid metabolism $[25,26]$. Therefore, the $\mathrm{Az}$ is now referred to as AtoC/Az, to indicate its dual function as both a transcriptional and post-translational regulator $[27,28]$.

TCSs are usually composed of an inner membrane sensor histidine kinase and a cognate response regulator, which frequently is a transcriptional activator [22]. Recent work from our laboratory has provided biochemical evidence that AtoS is indeed a membrane-bound sensor histidine kinase that phosphorylates the response regulator AtoC/ Az, both constituting a TCS $[27,28]$. The ability of a recombinant cytosolic region of AtoS to autophosphorylate, albeit at a very low rate, has also been demonstrated in a recent global analysis of $E$. coli TCSs [29]. The in vitro trans-phosphorylation of the AtoC/Az by a truncated form of its cognate AtoS kinase, where both proteins were expressed as recombinant his-tagged fusions, has also been demonstrated by our group (unpublished data). Acetoacetate is the only inducer of the AtoS-AtoC TCS identified thus far, for the activation of the AtoS-AtoC TCS. Upon activation, AtoS-catalyzed AtoC phoshorylation is essential for the transcriptional activation of the atoDAEB operon, the products of which are essential for the catabolism of short-chain fatty acids $[25,26]$. Recent global analyses of the E. coli TCSs $[29,30]$ have revealed that the AtoS-AtoC TCS might not affect solely atoDAEB regulation but it could be involved in a number of additional processes such as flagella synthesis, chemotaxis [29] and sodium but not potassium sensitivity [30]. The cross-regulation between AtoS-AtoC and EnvZ-OmpR TCSs has been also reported, as mutations in the latter TCS affect expression of atoC [29]. According to our data, the AtoS-AtoC TCS also acts directly on the atoDAEB operon transcription to enhance poly-hydroxy-butyrate (cPHB) biosynthesis in E. coli [31].

The Az levels are induced when polyamine levels rise [13], which is expected for a protein which elicits its effects by binding stoichiometrically to ODC. However, the mechanisms for this induction vary in different organisms. The mammalian antizyme levels are mainly regulated at the level of translation by polyamine-inducible programmed +1 ribosomal frameshifting [32], whereas the levels of the E. coli antizyme-like proteins S20 and L34 are regulated at the transcriptional level $[18,19]$.

Although the levels of the E. coli AtoC/Az have been found to increase upon cell exposure to high polyamine concentrations, there has been no evidence on the molecular basis of this induction. The aim of the present study was to elucidate the mechanism of polyamine-mediated induction of AtoC/Az in E. coli.

Polyamine analogues have been developed and used as probes in an effort to clarify the functions of natural polyamines $[33,34]$ as well as potential cancer chemotherapeutic agents and in treating several parasitic diseases [35-39]. Here we used 14 newly synthesized polyamine analogues as tools for monitoring the mechanism(s) by which endogenous polyamines: a) modulate AtoC/Az levels by affecting ato $C$ gene transcription, b) affect transcription of other genes that share a topological and/or functional relevance with atoC, i.e. the neighboring atoS 
gene, encoding the AtoS kinase of the AtoS-AtoC TCS, and the atoDAEB operon which is regulated by AtoC/Az, and c) alter the activity of ODC, the key enzyme for polyamine biosynthesis.

\section{Results \\ Effect of putrescine and spermidine on the transcription of the atoS-atoC two component system genes and the ato operon}

The ability of the reporter constructs (Fig 1), carrying lacZ fused to either of the promoters of the atoSC two component system (i.e the atoS or the ato $C$ promoter) or to its regulated genes, to respond to polyamines was evaluated in three E. coli strains. The isogenic E. coli strains, BW25113 and BW28878 that either carry the wild-type atoSC (BW25113) [29] or a deletion of the atoSC genomic region (BW28878) [30] and the MA255 strain (lacking ODC and AUH) [9], were transformed with the recombinant plasmids described at Fig. 1. Initially, polyamines were added in the growth medium as a mixture of putrescine and spermidine at the final concentrations of $0.3,0.5,1.0$ and $2.5 \mathrm{mM}$ each. The ability of the reporter constructs to respond to polyamines was determined, in all three E. coli strains, by assaying $\beta$-galactosidase expression. As shown in Fig. 2 \&3, polyamines caused activation of transcription of the ato $C$ gene in a polyamine concentration-dependent manner.

The specificity of this effect was demonstrated through the lack of activation upon polyamine addition, of either the ato operon promoter, when atoA-lacZ (Fig. 2 \&3) or atoD1-lac $Z$ constructs were used (extending 460 and 240 bp upstream of the translational start of atoD gene, respectively), or atoS (data not shown) for all three E. coli strains tested.

\section{Effect of the physiological polyamines and}

\section{diaminopropane on the activation of the ato $C$ gene}

In order to clarify which of the two polyamines played the major role in the transcriptional activation of the atoC gene the experiments were repeated in the presence of increasing concentrations of each polyamine. Specifically, E. coli MA255 carrying the reporter plasmid pCPG6 (atoClacZ) were grown in the presence of each of the polyamines diaminopropane, putrescine, spermidine or spermine $(0.05,0.3,0.5,1,2.5$ and $5 \mathrm{mM})$ alone. The results of the $\beta$-galactosidase assay suggested that putrescine and diaminopropane elicited a more pronounced effect in the transcriptional activation of the ato $C$ gene (Fig. 4). In contrast, spermidine and spermine not only failed to induce atoC but they slightly inhibited its expression.
Effect of polyamine analogues on the transcription of the ato $C$ and ato operon genes of $E$. coli strain MA255 (speB, spe $\left.C^{-}\right)$and BW25 I I 3 strain

A series of polyamine analogues (1-14, Fig. 5) has been synthesized and used to compare their biological effects with those of polyamines. These analogues were grouped into three structural types: the spermine analogues (Fig. 5a), the spermidine analogues (Fig. 5b) and the putrescine and diaminopropane analogues (Fig. 5c).

The effect of the polyamine analogues on the growth of a polyamine-dependent E. coli strain was investigated. E. coli MA255, whose growth depends on the presence of polyamines, were cultivated in media containing polyamine analogues $(1 \mathrm{mM})$ or $0.5 \mathrm{mM}$ putrescine and $0.5 \mathrm{mM}$ spermidine (i.e. $1 \mathrm{mM}$ in total). Following a longer lag period in the presence of the polyamine analogues, the bacteria displayed similar doubling times during the logarithmic phase irrespective of the polyamine or analogue used (data not shown).

The effects of polyamine analogues on ato $C$ and ato operon promoters were tested using E. coli strains MA255 and BW25113 carrying the appropriate reporter constructs, i.e. pCPG6 (atoC-lacZ) and pCPG5 (atoA-lacZ), and the results are presented in Tables $1 \& 2$. To facilitate comparisons between different sets of data, the $\beta$-galactosidase activities measured in the polyamine auxotrophic strain MA255 growing in the presence of $0.3 \mathrm{mM}$ of putrescine and spermidine (Table 1) or in the wild-type strain BW25113 growing in their absence (Table 2) were arbitrarily defined as $100 \%$.

It was found that some of these analogues activated the transcription of the reporter genes more than their parent polyamines. In general, the most potent transcriptional activators (compounds 10, 12 and 14) were putrescine and diaminopropane (DAP) analogues. Comparison of these two types of analogues (e.g. 8 against 12,9 against 13 and 11 against 14), revealed that the most active compounds were clearly the DAP analogues. Compound 14 was the most potent activator of both atoDAEB and atoC promoters. The effects appeared to be specific since some of the analogues showed different action on the two promoters since they stimulated, at least to a certain extend ato $C$ while they repressed the atoDAEB (ato) operon and vice versa. It is worth noticing that amongst spermine analogues, compound 4, bearing the strongly basic guanidine group on atoms $\mathrm{N}-4$ and $\mathrm{N}-9$ of the SPM backbone repressed the synthesis of both ato $C$ and atoDAEB operon.

To determine whether the above effects on gene expression were specific, or whether they resulted from polyamine analogue-induced stress effects on the cells exposed to them, we measured the levels of the heat shock 
(a)

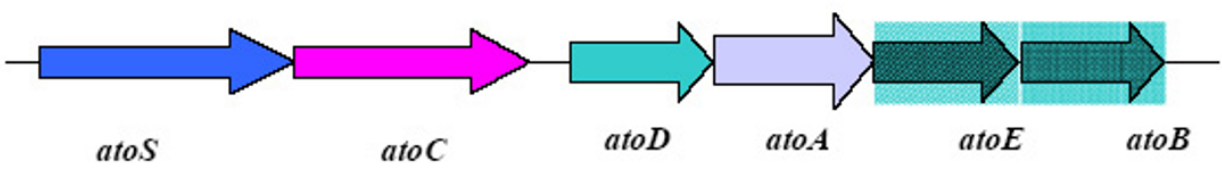

Histidine kinase Response Regulator atoDAEB operon

(b)
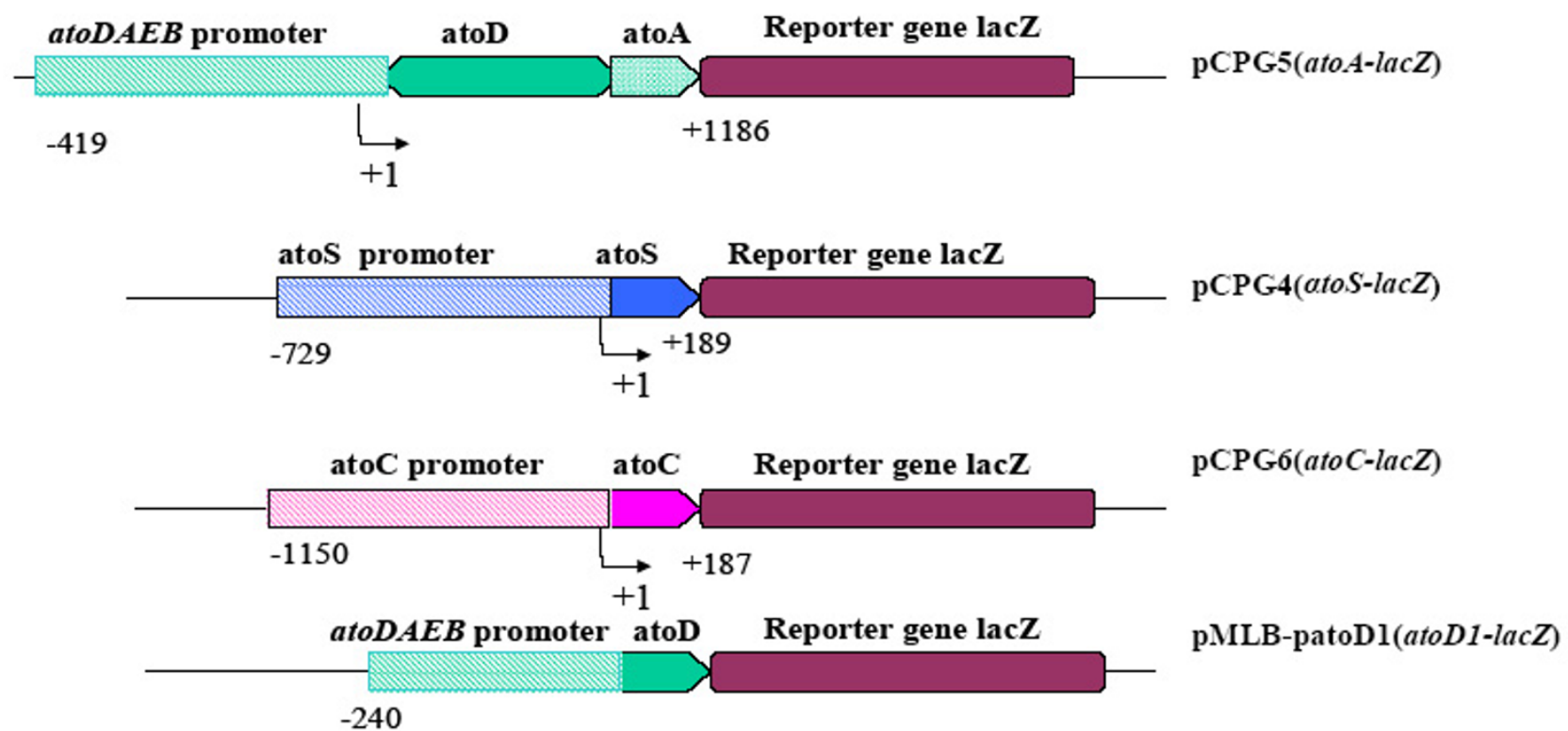

Figure I

a. Structural organization and direction of transcription of atoSCDAEB genes in E. coli.b. The constructs of plasmid pMLBI034 are carrying various promoters fused to a promoterless lacZ gene. PMLB-patoDI (atoDI-lacZ) and pCPG5 (atoA-lacZ) are carrying the promoter of the atoDAEB operon, extending 240 and $460 \mathrm{bp}$ upstream the translational start of the atoD gene respectively. PCPG4(atoS-lacZ) represents the promoter of atoS and a part of the atoS gene and PCPG6(atoC-lacZ) represents the promoter of atoC and a part of the atoC gene.

protein DnaK using immunoblot analysis. The absence of an increase in the DnaK levels in cells exposed to polyamine analogues indicated that they did not induce the heat-shock response (Fig. 6a).

\section{Polyamine and polyamine analogues effect on AtoC/Az protein levels}

Since polyamines and polyamine analogues activated the transcription of atoC/Az, it was investigated whether this activation also leads to AtoC/Az protein accumulation in the cell, thus affecting the translational mechanism.
Therefore, BW25113 cells were exposed to polyamines or their analogues, at the final concentration of $1 \mathrm{mM}$, grown to an $\mathrm{OD}_{600} 0.8-0.9$ and cell extracts were prepared as described for immunoblot analysis (Fig. 6b).

These experiments showed that AtoC/Az protein levels are induced by polyamines (lanes 3-5) and the most active polyamine analogues $(12,14$, lanes 6,8$)$. This induction is clear despite the very low intracellular levels of AtoC/Az, which was barely detectable in total extracts from cells growing in the absence of polyamines (lane 2). Extracts 


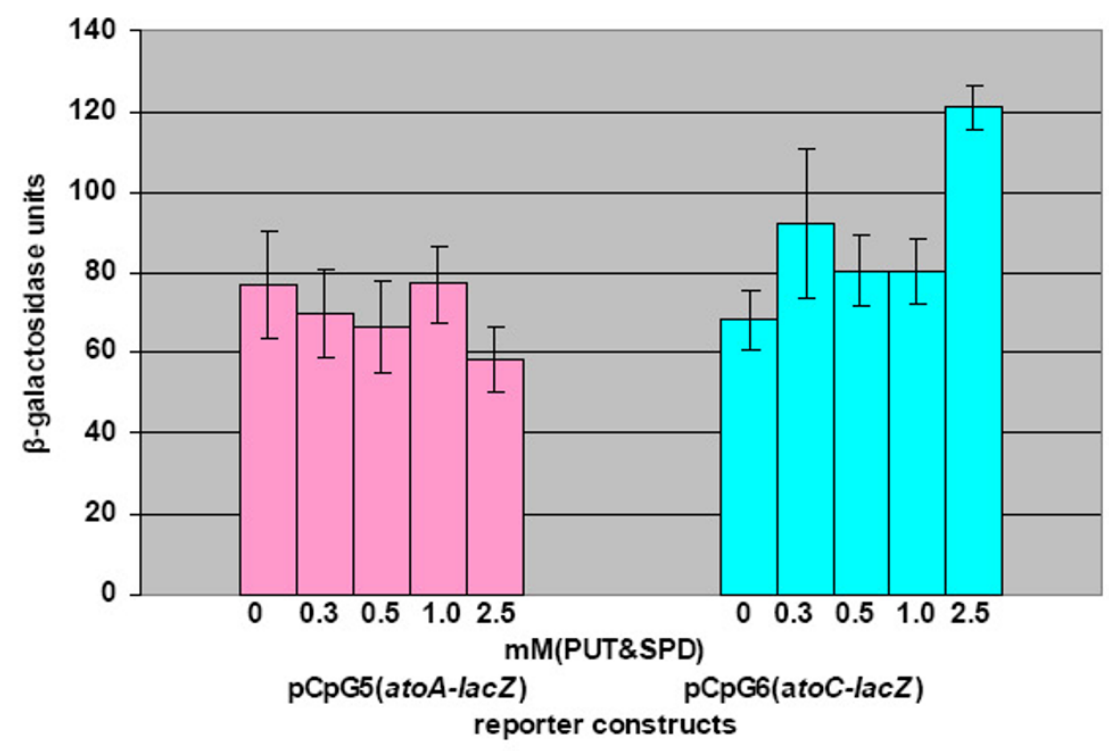

(a)

\section{E. coli K12 strain BW28878}

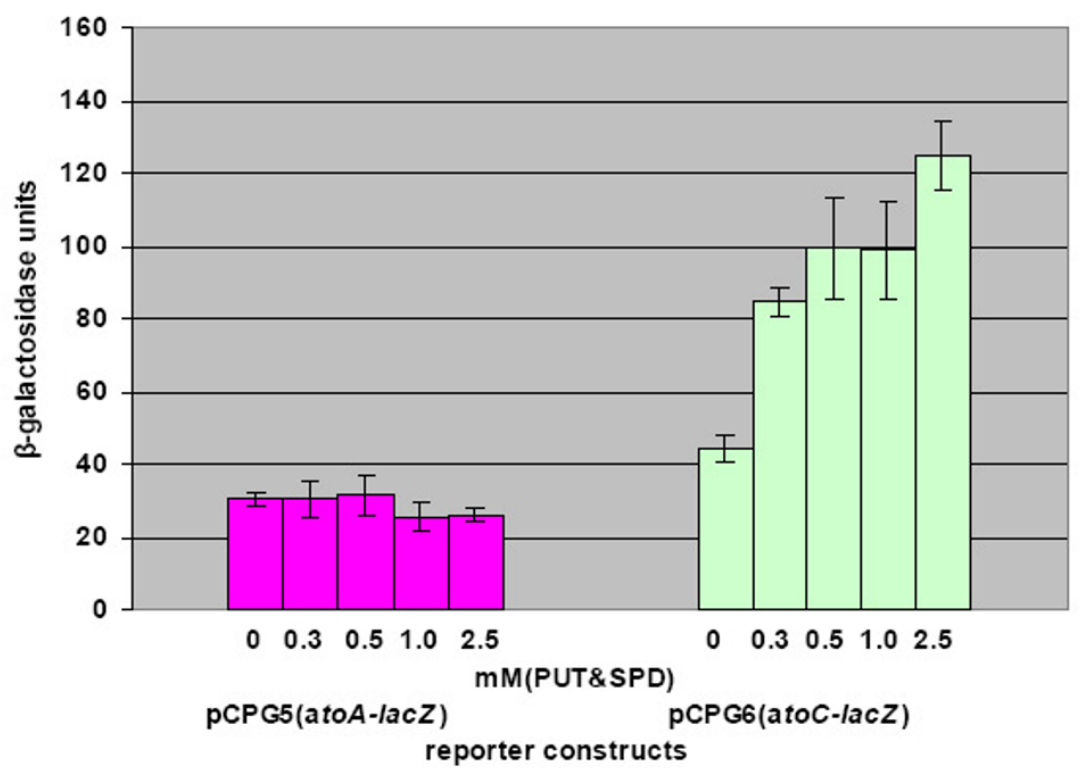

(b)

Figure 2

The effect of the polyamines PUT and SPD in the transcription of the atoSC two component system genes.(a)The $E$. coli KI2 strain BW25II 3 (atoSC ${ }^{+}$) and (b) E. coli KI2 strain BW28878(_atoSC), were transformed with recombinant plasmids, PCPG5(atoA-lacZ) and PCPG6(atoC-lacZ), carrying the various promoters of the atoSC two component system. Polyaminemediated induction was measured by assaying $\beta$-galactosidase expression in the presence of increasing concentrations of polyamines $(0,0.3,0.5, \mathrm{I}$ and $2.5 \mathrm{mM})$. The results are presented from three independent experiments, while in each experiment two clones from each transformant were tested. 


\section{E. coli K12 strain MA255}

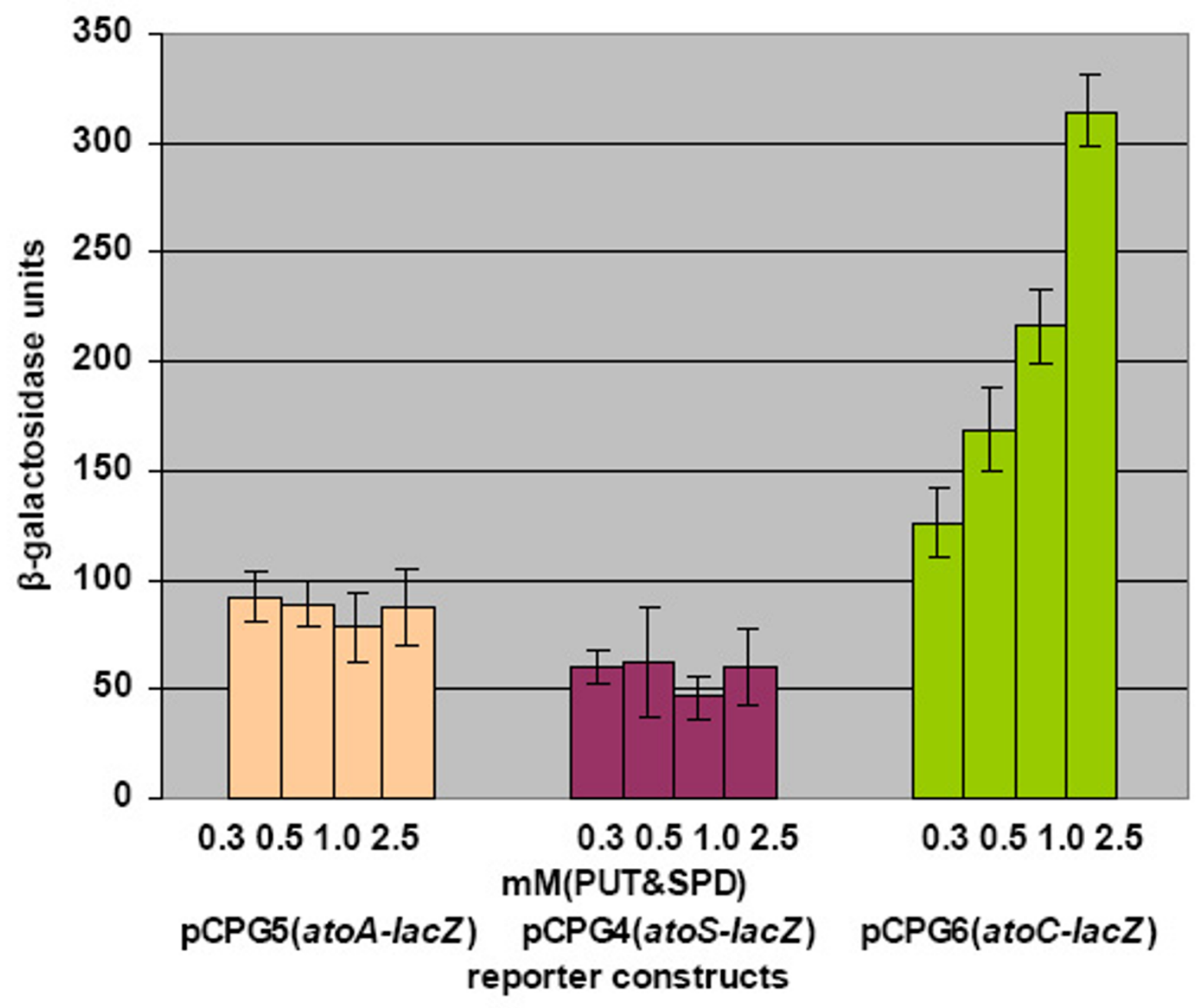

Figure 3

The effect of polyamines in the transcription of the atoSC genes in E. coli strain MA255. The E. coli KI2 strain MA255 was transformed with plasmids PCPG4(atoS-lacZ), pCPG5(atoA-lacZ) and PCPG6(atoC-lacZ). Polyamine-mediated induction was measured by assaying $\beta$-galactosidase expression in the presence of the indicated concentrations of polyamines (in $\mathrm{mM}$ ).

from cells lacking the AtoC/Az protein (BW28878) were used as negative control and BW25113 cells transformed with plasmid pUC-Az [21] overexpressing AtoC/Az were used as a positive control for the blot.

\section{Effect of polyamine analogues on ODC activity and protein levels}

It has been demonstrated that polyamines cause a decrease in the E. coli ODC mRNA and protein levels and that the specific activity of ODC decreases significantly more than its protein levels, due to its post-translational inhibition by antizyme(s) $[9,18,19]$. Considering that the polyamine analogues, like polyamines can affect gene expression, their effects on ODC activity were also investigated.

Thus, the ODC activity was assayed in vitro using extracts from polyamine analogue-exposed E. coli cells. These extracts were prepared from cells grown in the mineral medium $\mathrm{M} 9$ to $\mathrm{OD}_{600} 0.8-0.9$ and the assays were performed as described in Methods. Provided that some polyamine analogues behaved like natural polyamines, it 


\section{MA255/pCPG6(atoC-lacZ)}

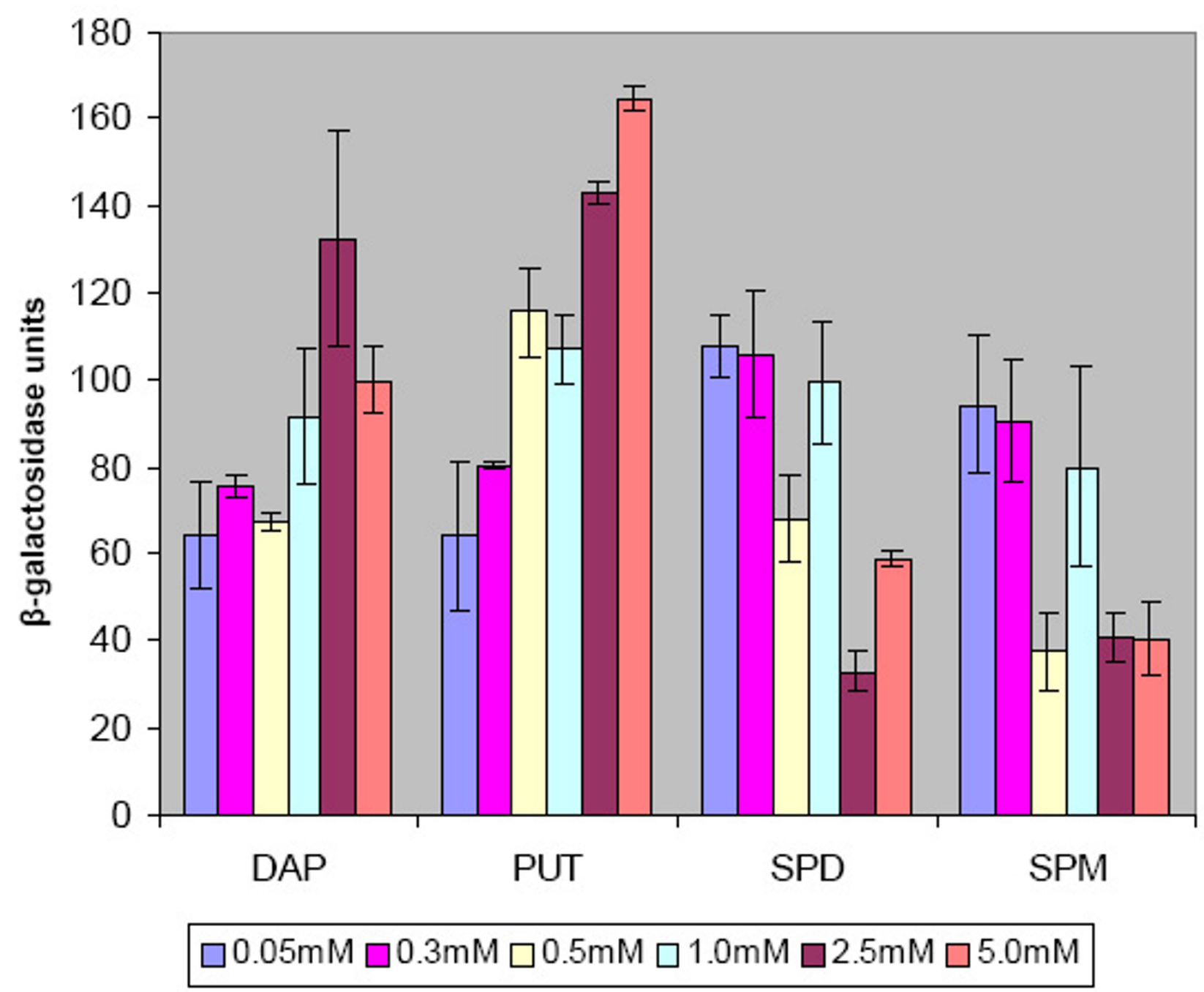

Figure 4

The effect of each polyamine alone PUT, DAP, SPD and SPM in the transcription of the atoC gene in E. coli strain MA255. Increasing concentrations of each polyamine were added in the growth medium (see Methods) and the transcriptional activity of the reporter construct PCPG6(atoC-lacZ) was measured by assaying $\beta$-galactosidase activity.

was expected that the specific activity of ODC would decrease as the levels of AtoC/antizyme, its post-translational inhibitor, rise [19].

Table 3 shows that indeed E. coli exposure to some of the polyamine analogues decreased the ODC specific activity. It is interesting that the polyamine analogue 14 , which has the highest negative impact on ODC specific activity
(Table 3) was also found to be the most potent activator of atoC expression (Tables 1 \&2).

Since growth of $E$. coli cells in the presence of polyamines results in decreased ODC protein levels [19], it was investigated whether the reduced ODC activity in extracts from polyamine analogue-exposed cells (Table 3 ) similarly resulted from such a reduction. Immunoblot analysis, 
(a)
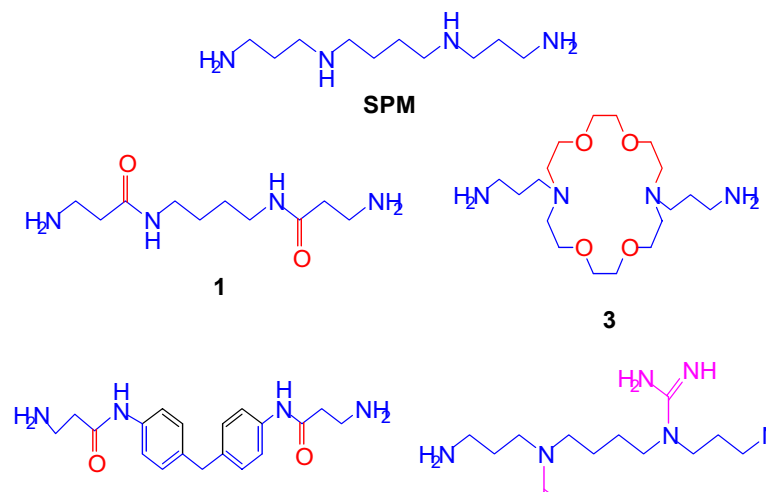

2

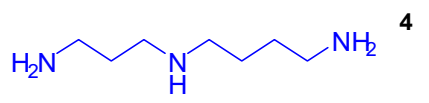

(b)

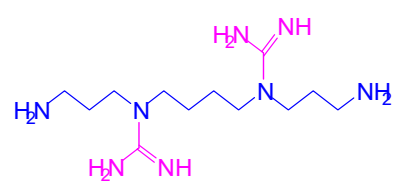

)

SPD<smiles>NCCCCNC(=O)CCN</smiles>

5<smiles>N=C(N)N(CCCCN)CCCCN</smiles><smiles>NCCCCn1nnnc1CCN</smiles>

(c)<smiles>NCCCCCN</smiles><smiles>NCCC[18OH]</smiles><smiles>NCCCC(=O)NCc1ccccc1</smiles>

8<smiles>NCCCc1nnnn1Cc1ccccc1</smiles>

9<smiles>NCCCc1nnn[nH]1</smiles>

10
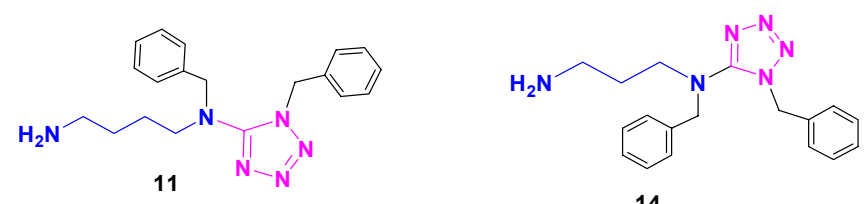

Figure 5

Structures of a. SPM, I-4, b. SPD, 5-7, c. PUT, 8-I I and DAP, I 2-I 4, analogues. 
Table I: Effect of polyamine analogues in the transcriptional activation of the atoC gene and atoDAEB operon in E. coli strain MA255.

\begin{tabular}{|c|c|c|}
\hline SUBSTANCES & $\begin{array}{c}\% \beta \text {-galactosidase activity MA255/ } \\
\text { (atoC-lacZ) }\end{array}$ & $\begin{array}{c}\% \beta \text {-galactosidase activity MA255/ } \\
\text { (atoA-lacZ) }\end{array}$ \\
\hline Control (Putrescine \& spermidine/0.3 mM each) & $100 \%$ & $100 \%$ \\
\hline \multicolumn{3}{|c|}{ I $\mathrm{mM}$ concentration } \\
\hline \multicolumn{3}{|c|}{ SPERMINE ANALOGUES } \\
\hline $\mathbf{I}$ & $67 \pm 4.86$ & $200 \pm 10.66$ \\
\hline 2 & $142 \pm 8.69$ & $181 \pm 2.09$ \\
\hline 3 & $135 \pm 4.69$ & $177 \pm 1.39$ \\
\hline 4 & $43 \pm 3.11$ & $38 \pm 2.38$ \\
\hline \multicolumn{3}{|c|}{ SPERMIDINE ANALOGUES } \\
\hline 5 & $78 \pm 2.56$ & $155 \pm 9.12$ \\
\hline 6 & $179 \pm 10.9$ & $114 \pm 3.66$ \\
\hline 7 & $110 \pm 8.50$ & $208 \pm 8.80$ \\
\hline \multicolumn{3}{|c|}{ PUTRESCINE ANALOGUES } \\
\hline 8 & $108 \pm 10.93$ & $59 \pm 5.74$ \\
\hline 9 & $119 \pm 7.34$ & $43 \pm 8.80$ \\
\hline 10 & $124 \pm 10.30$ & $64 \pm 10.66$ \\
\hline II & $172 \pm 6.42$ & $45 \pm 5.85$ \\
\hline \multicolumn{3}{|c|}{ DIAMINOPROPANE ANALOGUES } \\
\hline 12 & $248 \pm 8.02$ & $69 \pm 8.14$ \\
\hline 13 & $169 \pm 8.66$ & $111 \pm 10.24$ \\
\hline 14 & $452 \pm 2.17$ & $218 \pm 6.77$ \\
\hline
\end{tabular}

The data are presented as \% activity of $\beta$-galactosidase for MA255 cells grown in the presence of $0.3 \mathrm{mM}$ putrescine and spermidine and I mM of the indicated polyamine analogue. The values represent the means \pm SD from two separate experiments.

with a rabbit polyclonal anti-ODC antibody, was performed to measure the levels of ODC protein in the same extracts as those used for the in vitro ODC assays. These experiments indicated that, despite their negative effects on ODC activity, the polyamine analogues caused no reduction on the ODC protein levels (Fig 7.)

\section{Discussion}

Polyamines are essential cellular components for the growth and proliferation of all living cells. Regulation of polyamine biosynthesis is complex and the key biosynthetic enzyme ODC, is one of the most highly regulated enzymes [7], the levels and/or activity of which are modulated at the transcriptional, translational and post-translational levels [8].

Antizyme is long known as a polyamine-inducible, noncompetitive inhibitor of ODC [9,13-15]. Az has also been found to be the product of atoC gene whose product is the response regulator of the AtoS-AtoC two component system. Recent work from our laboratory has shown that AtoS and AtoC indeed constitute a two component system and that they participate in atoDAEB operon expression upon acetoacetate induction $[27,28]$.

E. coli $\mathrm{Az}$ is induced by polyamines and inhibits the activity of ODC by forming an Az-ODC complex [9]. Little is known, however, about the mechanism of this induction, in contrast to the eukaryotic antizyme, which is induced by polyamines at the translational level $[27,32]$.

In this work we attempted to elucidate the way by which polyamines induce AtoC/Az in E. coli and furthermore to clarify their effect in the transcription of other genes that share a topological and/or functional relevance with atoC/ $A z$. The measurement of the $\beta$-galactosidase activity in cells carrying various promoter-laZ constructs indicated that ato $C$, but no other gene tested, expression was activated upon growth in increasing polyamine concentrations. This activation in atoC expression was not strainspecific since it was manifested in all three E. coli strains studied.

The combination of both putrescine and spermidine was not required since ato $C$ expression was found to be induced by each polyamine alone (Fig. 4). The data derived from both E. coli MA255 (Fig. 4) and BW25113 strains (Table 2) indicated that PUT and the non-natural diamine DAP were the main transcriptional effectors. The in vivo transcriptional effects of DAP and PUT suggested that a distance of three to four carbon atoms between the two amino groups had the maximal effect on the transcriptional activation of the atoC. The specificity of PUT and DAP to exert this effect was strengthened by the inability of the multivalent SPD or SPM to activate the atoC gene. 
Table 2: Effect of polyamine analogues in the transcriptional activation of the atoC gene and atoDAEB operon in E. coli strain BW25II3.

\begin{tabular}{|c|c|c|}
\hline SUBSTANCES & $\begin{array}{c}\% \beta \text {-galactosidase activity BW25 I I 3/ } \\
\text { (atoC-lacZ) }\end{array}$ & $\begin{array}{c}\% \beta \text {-galactosidase activity BW25 I I3/ } \\
\text { (atoA-lacZ) }\end{array}$ \\
\hline Control (No polyamines added) & $100 \%$ & $100 \%$ \\
\hline \multicolumn{3}{|c|}{ I mM concentration } \\
\hline \multicolumn{3}{|c|}{ SPERMINE ANALOGUES } \\
\hline spermine & $98 \pm 3.38$ & $88 \pm 1.98$ \\
\hline I & $98 \pm 1.9$ & $80 \pm 5.96$ \\
\hline 2 & $156 \pm 1.62$ & $79 \pm 1.59$ \\
\hline 3 & $80 \pm 1.41$ & $58 \pm 2.49$ \\
\hline 4 & N.D & N.D \\
\hline \multicolumn{3}{|c|}{ SPERMIDINE ANALOGUES } \\
\hline spermidine & $105 \pm 1.38$ & $107 \pm 3.37$ \\
\hline 5 & $107 \pm 1.82$ & $60 \pm 2.84$ \\
\hline 6 & $128 \pm 1.73$ & $52 \pm 3.76$ \\
\hline 7 & N.D & N.D \\
\hline \multicolumn{3}{|c|}{ PUTRESCINE ANALOGUES } \\
\hline putrescine & $170 \pm 4.29$ & $110 \pm 3.28$ \\
\hline 8 & $125 \pm 1.63$ & $76 \pm 1.93$ \\
\hline 9 & N.D & N.D \\
\hline 10 & $216 \pm 3.92$ & $233 \pm 6.30$ \\
\hline II & N.D & N.D \\
\hline \multicolumn{3}{|c|}{ DIAMINOPROPANE ANALOGUES } \\
\hline diaminopropane & $200 \pm 4.19$ & $87 \pm 2.26$ \\
\hline 12 & $238 \pm 6.44$ & $128 \pm 5.47$ \\
\hline 13 & $\mid 85 \pm 9.81$ & $202 \pm 9.68$ \\
\hline 14 & $303 \pm 6.80$ & $193 \pm 7.35$ \\
\hline
\end{tabular}

Data are presented as \% activity of $\beta$-galactosidase for BW 25113 cells grown in the absence of polyamines or in the presence of the indicated polyamine or polyamine analogue. The values represent the means \pm SD from two separate experiments.

Subsequently 14 polyamine analogues were synthesized and tested both for their ability to support the growth of a polyamine-dependent E. coli strain and to affect an essential biological process, such as the transcriptional activation of genes of atoDAEB operon.

Most of these analogues, at the final concentration of 1 $\mathrm{mM}$, were used by E. coli strain MA255 as carbon sources and supported cell growth. The analogues demonstrated a differential effect on gene expression as evidenced by the facts that: i) a number of analogues activated the atoC transcription, without affecting the transcription of the ato operon (compound 12) and vice versa (compounds 1\&7) and ii) some of the analogues seemed to activate both the atoDAEB (atoA-lacZ) and the atoC transcription (atoClacZ) (compounds 10, 14, Table 2.). These results could not attributed to a broad effect of these compounds, since the levels of the heat shock protein DnaK were not affected, as shown by immunoblot analysis of total extracts of cells exposed to these analogues (Fig. 6a).

Analysis of the effects of the different analogue types on ato $C$ gene expression (e.g. 8 against 12, 9 against 13 and 11 against 14), revealed that the most active compounds were the DAP analogues, with compound 14 being the most potent. These data established the significance of charge distribution and chain flexibility on polyamine mode of action in atoC transcription.

In the cases where both atoC and atoDAED were activated by the analogues, the activation of atoDAEB could not be attributed to the enhanced intracellular accumulation of AtoC/Az, the product of atoC, but rather to their direct effects on atoDAEB transcription. This is surprising since none of the physiological polyamines produced an analogous effect.

The regulatory role of $\mathrm{Az}$ in the feed-back inhibition of ODC, the rate limiting enzyme in polyamine biosynthesis, was investigated by the ability of the PUT and DAP synthetic analogues to reduce the ODC activity in E. coli. The inhibition of ODC activity by these analogues (Table 3 ) could result from negative transcriptional effects of the polyamine analogues on $s p e C$, the gene that encodes ODC, or/and indirectly through antizyme induction, the intracellular accumulation of which would increase the proportion of ODC-Az inactive complex. The latter possibility was more probable in view of the fact that several polyamine analogues activated the expression of atoC, which encodes antizyme. Indeed, immunoblot analysis 


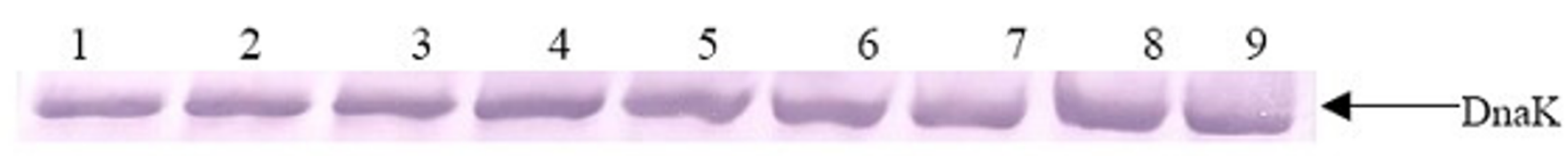

(b)

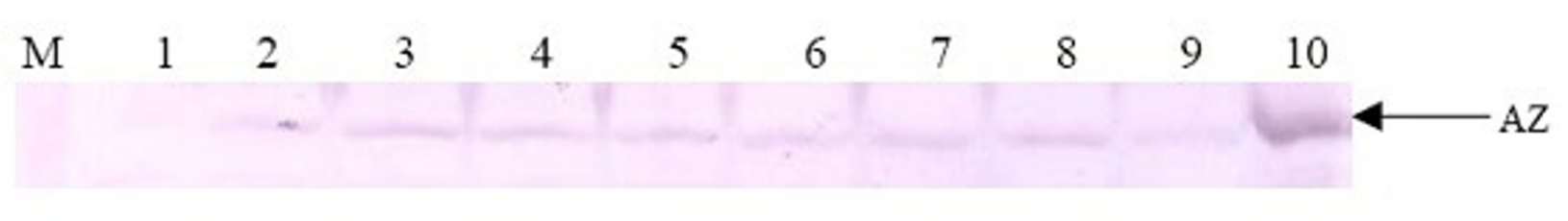

\section{Figure 6}

a Effect of polyamines or polyamine analogues on endogenous DnaK expression. Western blot of total cell extracts of $E$. coli $\mathrm{K} 12$ cells BW25II3 (atoSC+ $)$ grown to an $\mathrm{OD}_{600} 0.8-0.9(15 \mu \mathrm{l})$, was performed to detect the expression of the heat shock protein DnaK. Lane I: BW25II 3 cells with no inducer. Lanes 2-4: BW25I I 3 cells treated with PUT, SPD, or SPM, respectively. Lanes 5-9: BW25II 3 cells treated with I mM polyamine analogue 2, 10, 12, 13, 14, respectively. $\mathbf{6}$ b. Effect of polyamines or polyamine analogues on endogenous AtoC/Az expression. The $E$. coli K I 2 cells BW25II3(atoSC $C^{+}$were cultured in the presence of I mM of the indicated polyamine analogue or each polyamine, respectively. Total cell extracts of each culture grown to an $\mathrm{OD}_{600} 0.8-0.9(20 \mu \mathrm{l})$ were analyzed. The immunoblot analysis was performed using the purified polyclonal rabbit antibody of AtoC/Az. BW28878 cells, not expressing the atoC/Az protein, were used as negative control. The high copy plasmid pUC-Az [2I], overexpressing the AtoC/Az protein, was used as a positive control. Lane I: BW28878 cells, Lane 2: BW25I I 3 cells with no inducer Lanes 3-5: BW25 I 3 cells treated with PUT, SPD or SPM, respectively. Lanes 6-9: BW25II 3 cells treated with analogues 10, 12, 14, 13. Lane 10: BW25II 3 cells carrying the PUC-Az plasmid.

Table 3: Effect of polyamine analogues on ODC activity.

\begin{tabular}{|c|c|c|c|c|}
\hline BW25 I I 3 strain/ I mM Substance & $\%$ ODC activity & $\%$ Inhibition of ODC activity & ODC Units/I $0 \mu$ I & $\begin{array}{l}\text { Specific ODC activity } \\
\text { (Units/mg protein) }\end{array}$ \\
\hline Control & 100 & 0 & 4.79 & $239.5 \pm 3.5$ \\
\hline PUT & 40.66 & 59.33 & 1.95 & $84.78 \pm 0.5$ \\
\hline SPD & 47.89 & 52.11 & 2.29 & $76.33 \pm 0.2$ \\
\hline SPM & 76.94 & 23.06 & 3.68 & $153.33 \pm 2.5$ \\
\hline 8 & 74.98 & 25.02 & 3.59 & $211.17 \pm 4.0$ \\
\hline 10 & 51.78 & 48.22 & 2.48 & $118.09 \pm 0.3$ \\
\hline 12 & 37.52 & 62.48 & 1.79 & $99.44 \pm 1.5$ \\
\hline 13 & 61.36 & 38.64 & 2.94 & $108.88 \pm 2.3$ \\
\hline 14 & 56.82 & 43.18 & 2.72 & $82.42 \pm 0.2$ \\
\hline
\end{tabular}

E. coli BW25II 3 was grown to an $\mathrm{OD}_{600} 0.8-0.9$ in M9 medium in the absence (control) or in the presence of I mM polyamine (PUT, SPD, SPM) or I mM polyamine analogue. ODC activity and protein levels were determined as described in Materials and Methods. Specific activities are expressed as $\mu \mathrm{mol}{ }^{14} \mathrm{CO}_{2}$ liberated/mg enzyme protein/h of incubation. The values represent the means \pm SD from two separate experiments. 


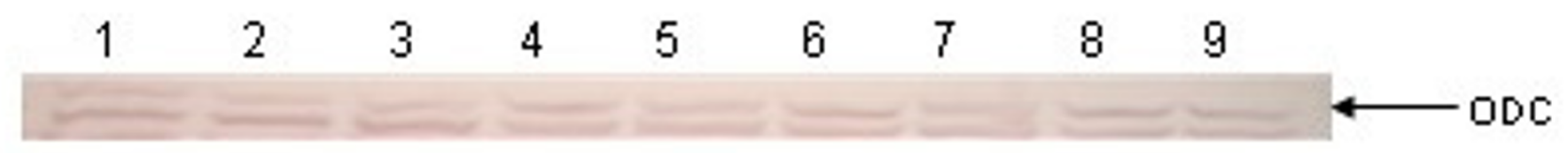

Figure 7

Effect of polyamine analogues on endogenous ODC expression. E. coli KI 2 cells BW25II 3 (atoSC ${ }^{+}$) were grown in the presence of I $\mathrm{mM}$ of the indicated polyamine or polyamine analogue, to a cell density of $0.8-0.9$. The total cell extracts from each culture $(20 \mu \mathrm{l})$ were subjected to SDS-PAGE I0\% and immunostained with anti-ODC. Lane I: BW25 I I 3 cells, with no inducer added. Lanes 2-4: BW25 I I 3 cells, treated with I mM PUT or SPD or SPM. Lanes 5-9: BW25 I I3 cells treated with I mM of each polyamine analogue $8,10,12,13$ and 14 , respectively.

indicated that the analogues that activated ato $C$ transcription also produced increased $\mathrm{Az}$ accumulation, without affecting ODC protein levels (Fig. 6b and 7).

Interestingly, elevated levels of ODC have been associated with highly proliferating cells $[2,3,5,7,13,33]$ and polyamine analogues as well as drugs that influence intracellular polyamine levels have shown antiproliferative activity [35-38]. Despite the differences between bacterial and eukaryotic mechanisms that govern Az induction and regulation of polyamine biosynthesis, substances that act as inducers of Az could reduce polyamine levels and provide a lead for the development of agents capable of cell growth arrest.

\section{Conclusion}

Polyamines, which have been reported to induce AtoC/Az in $E$. coli, activated the expression of atoC, the gene that encodes AtoC/Az. A series of synthetic polyamine analogues have been tested for their effectiveness on the expression of the atoC, as well as that of the atoDAEB (ato) operon. Putrescine and diaminopropane analogues, activated atoC transcription, indicative of the structural requirements of diamines for $\mathrm{Az}$ induction. In addition, this ato $C$ induction resulted in accumulation of $A z$ protein and inhibition of ODC activity. This inhibition is likely due to the formation of inactive ODC-Az complexes, since in bacteria grown in the presence of polyamine analogues did not affect the ODC protein levels.

\section{Methods}

\section{Bacterial strains, plasmids and culture conditions} Bacterial strains

E. coli K-12 strains were transformed with the appropriate plasmids. E. coli strain MA255 [F-, thr, leuB6(Am), fhuA2?, lacY1, glnV44(AS)?, gal-6, $\lambda$-, relA1?, CanR?-1, speB, speC, rpsL133(strR), $\chi y l A 7, m t l A 2$, thi $^{-}$] was obtained from $E$. coli genetic stock Center, Department of MCDB, Yale university.

E. coli K-12 BW25113 [lacI9 rrnB3 $\Delta l a c Z 4787$ hsdR514 $\mathrm{DE}(a r a B A D) 567 \mathrm{DE}(r h a B A D) 568 r p h-1]$ and BW28878 [BW25113, lacking AtoS-AtoC system, $\triangle a t o S C]$ were a kind gift from Dr Hirofumi Aiba (Laboratory of Molecular Microbiology, School of Agriculture, Nagoya University, Japan).

\section{Plasmids}

The genetic organisation of the ato locus is shown in Figure $1 \mathrm{a}$. The plasmids used in this study are carrying various promoters of genes, fused to a promoterless lac $Z$ gene on pMLB1034 vector. These reporter constructs, carrying the promoters of the ato operon and the regulatory atoSato $C$ two component system genes, can direct the synthesis of the lac $Z$ gene under the control of their cognate promoters. pCPG4 (atoS-lacZ), pMLB-patoD1(atoD1-lacZ), pCPG5 (atoA-lacZ) and pCPG6 (atoC-lacZ), are carrying the atoS promoter, various lengths of the atoDAEB promoter (extending 240 and 460 bp upstream the translational start of the atoD gene, respectively) and the ato $C$ promoter (Fig 1b)

\section{Culture conditions}

E. coli cells were grown at $37^{\circ} \mathrm{C}$ with vigorous shaking in $\mathrm{M}_{9}$ minimal medium [40], supplemented with $0.1 \mathrm{mM}$ $\mathrm{CaCl}_{2}, 1 \mathrm{mM} \mathrm{MgSO}{ }_{4}, 0.5 \% \mathrm{w} / \mathrm{v}$ glucose, $1.7 \mu \mathrm{M} \mathrm{FeSO}_{4}, 1$ $\mu \mathrm{g} / \mathrm{ml}$ thiamine, $50 \mu \mathrm{g} / \mathrm{ml}$ DL-leucine and threonine (for the growth of MA255) and $80 \mu \mathrm{g} / \mathrm{ml}$ DL-proline (for BW25113 and BW28878 strains). Ampicillin was used at the final concentration of $100 \mu \mathrm{g} / \mathrm{ml}$.

E. coli strain MA255 lacking the biosynthetic enzymes ODC and agmatine ureohydrolase (AUH), is unable to synthesize polyamines and grows only in the presence of 
exogenously supplied polyamines. Therefore, polyamines (PUT and SPD) were also added in the growth medium at the final concentration of $0.05 \mathrm{mM}$ which was the lowest concentration necessary for growth.

The strains to be tested were grown overnight, then diluted 10 -fold in the growth medium containing polyamines or polyamine analogues and the cells were grown to $\mathrm{OD}_{600} 0.4-0.7$. The cells were harvested by centrifugation at $8000 \times \mathrm{g}$ and washed twice with $\mathrm{M}_{9}$ before the $\beta$-galactosidase assay.

For the in vitro ODC activity assay, E. coli cells were grown in $M_{9}$ mineral medium, in the absence or presence of 1 $\mathrm{mM}$ polyamines or polyamine analogues. The cells were harvested when the cultures reached late logarithmic phase $\mathrm{OD}_{600} 0.8-0.9$ by centrifugation at $8000 \times \mathrm{g}$ for 10 min. The cell pellets were washed twice with ice-cold buffer saline and stored at $-20^{\circ} \mathrm{C}$ until use.

\section{$\beta$-Galactosidase assay}

$\beta$-Galactosidase activity assays were performed using the the E. coli MA255 (speC-, speB-), BW25113 (atoSC ${ }^{+}$) and BW28878( $\triangle a t o S C)$, carrying the appropriate plasmids, as described previously [40]. In all experiments, strains carrying plasmid pMLB1034 were used as negative controls.

\section{Immunoblot analysis}

An aliquot of $1 \mathrm{ml}$ of each culture prepared as decribed for the $\beta$-galactosidase assays or ODC activity assays, was centrifuged and resuspended in SDS loading buffer of $1.5 \mathrm{X}$ (75 mM Tris-HCl pH 6.8, 3\% w/v SDS, $0.15 \% \mathrm{w} / \mathrm{v}$ bromophenol blue, $15 \% \mathrm{v} / \mathrm{v}$ glycerol and $\beta$-mercaptoethanol at a final concentration of $10 \% \mathrm{v} / \mathrm{v}$ ), boiled for 5 minutes and kept at $-20^{\circ} \mathrm{C}$ for immunoblot analysis.

\section{ODC activity assay}

The cell pellets were suspended in $0.5 \mathrm{ml}$ ice-cold ODC assay buffer ( $50 \mathrm{mM}$ Tris-HCl pH 8.2, $0.1 \mathrm{mM}$ EDTA, 50 $\mu \mathrm{M}$ 5'-phosphate pyridoxal, $5 \mathrm{mM}$ dithiothreitol), disrupted by sonication in an ice bath for $12 \mathrm{~min}$ and centrifuged at $10,000 \times \mathrm{g}$ for $10 \mathrm{~min}$ at $4^{\circ} \mathrm{C}$. Enzyme activity of ODC was assayed in the supernatant of each culture. $10 \mu \mathrm{l}$ of each supernatant, was incubated with $35 \mu \mathrm{l}$ ODC assay buffer and $5 \mu \mathrm{lDL}-\left[1-{ }^{14} \mathrm{C}\right]$ ornithine $0.028 \mu \mathrm{mol}$, for $1 \mathrm{~h}$ at $37^{\circ} \mathrm{C}$. The reaction was terminated with the addition of $0.2 \mathrm{ml}$ of $10 \%$ trichloroacetic acid. ODC activity was measured from the liberation of ${ }^{14} \mathrm{CO}_{2}$ from the DL-[1${ }^{14} \mathrm{C}$ Jornithine, which was captured on filter paper that was pre-treated with $25 \mu \mathrm{l}$ soluene-350 and air dried. Filter paper was placed in liquid scintillation fluid. Radioactivity was counted as DPM and expressed in units, as it was defined [9]. The remainder of supernatant was analyzed for protein concentration using Bradford method [41].

\section{Synthesis of polyamine analogues}

Spermine analogues I-4

These compounds were obtained, as the corresponding di- $(1,2)$ and tetra- $(3,4)$ trifluoroacetate salts, through routine trifluoroacetic acid (TFA)-mediated deprotection of the corresponding fully protected, with the trityl (primary amino functions) and the tert-butoxycarbonyl (guanidine functions) protecting groups, precursors. The precursors to compounds 1 and 3 and 2 and 4 were obtained according to reported procedures $[42,43]$.

\section{Spermidine analogues 5-7}

These compounds were obtained, as the corresponding di- $(5,7)$ and tri- $(6)$ trifluoroacetate salts, through routine trifluoroacetic acid(TFA)-mediated deprotection of the corresponding fully protected, with the trityl (primary amino functions) and the tert-butoxycarbonyl (guanidine function) protecting groups, precursors (Fig. 5b). The precursors to compounds 5 and 6 [42-44] and to the compound 7 [45] were obtained according to reported procedures.

\section{Putrescine analogues 8- 14}

Compounds 8, 9, 12 and 13 were obtained, as the corresponding trifluoroacetate salts, through routine trifluoroacetic acid (TFA)-mediated deprotection of the corresponding protected, with the trityl (primary amino function) protecting group, precursors (fig. 5c). The precursors to compounds $8,9,12$ and 13 were prepared according to reported procedure [45]. Compound 10 was obtained from the $N$-tritylated compound 9, through catalytic hydrogenolysis [45]. Finally, compounds 11 and 14 were prepared, as the corresponding trifluoroacetate salts, through routine trifluoroacetic acid (TFA)-mediated deprotection of the corresponding protected, with the trityl (primary amino function) protecting group, precursors. The latter were obtained according to a recently developed protocol in our laboratory for the selective $N$ tetrazolation of polyamines.

\section{Antibody purification}

The rabbit polyclonal antibodies against E. coli ODC, Az and DnaK used in this study have been described $[19,28,48]$. The anti-Az antibody was negatively purified against cross-linked total protein extracts from the $A z-E$. coli strain BW28878. E. coli cells BW28878 were grown in Luria-Bertani (LB) at $37^{\circ} \mathrm{C}$ to an $\mathrm{OD}_{600} 1.5$, were harvested and washed twice with saline. Cells were suspended in ice-cold lysis buffer $\left(50 \mathrm{mM} \mathrm{NaH} \mathrm{PO}_{4}, 300\right.$ $\mathrm{mM} \mathrm{NaCl})$ and lysed by lysozyme treatment $\left(1 \mathrm{mg} \cdot \mathrm{ml}^{-1}\right)$, for $60 \mathrm{~min}$ at $4{ }^{\circ} \mathrm{C}$, and sonication. The cell lysate was centrifuged at $9,000 \times \mathrm{g}$ (SS-34 rotor) for $20 \mathrm{~min}$ at $4{ }^{\circ} \mathrm{C}$ to remove cell debris and unbroken cells and the supernatant was treated with DNAse I ( 3 units. $\mathrm{ml}^{-1}$ ) and RNAse A $\left(10 \mu \mathrm{g} . \mathrm{ml}^{-1}\right)$ for $30 \mathrm{~min}$ at $4{ }^{\circ} \mathrm{C}$. The lysate was further cen- 
trifuged at $9,000 \times \mathrm{g}\left(\mathrm{SS}-34\right.$ rotor) for $20 \mathrm{~min}$ at $4^{\circ} \mathrm{C}$. The supernatant was stirred with formaldehyde $1 \%$ at $4^{\circ} \mathrm{C}$ for 1 hour. $0.2 \mathrm{M}$ Glycine was then added to react with the remaining formaldehyde, for 30 minutes. The cross-linking of proteins by formaldehyde led to the formation of a white protein complex. The protein pellet was centrifuged at $8000 \times \mathrm{g}$ for $15 \mathrm{~min}$, washed three times with $5 \mathrm{ml}$ PBSGlycine $0.2 \mathrm{M}, \mathrm{pH} 8.0$ and incubated overnight at $4{ }^{\circ} \mathrm{C}$ with the $400 \mu \mathrm{l}$ serum of the rabbit polyclonal antibody of antizyme. The protein pellet of BW28878 cells could absorb all the antibodies except from that of Az because of the lack of the AtoSC proteins. The serum was centrifuged and the supernatant is the purified antibody used for the immunoblot analysis in this study.

\section{Electrophoresis and immunoblotting}

SDS-polyacrylamide gel electrophoresis (SDS-PAGE) was performed using $10 \%(\mathrm{w} / \mathrm{v})$ polyacrylamide gels, as described by Laemmli et al [46]. Proteins were transferred to immobilon PVDF membranes following the method of Towbin et al. [47] and immunostained with the rabbit polyclonal antibodies against, ODC, Az and DnaK, respectively, prepared as described $[19,28,48]$.

\section{Abbreviations}

ODC, ornithine dacarboxylase; $\mathrm{AUH}$, agmatine ureohydrolase; Az, antizyme; TCS, two component system; PUT, putrescine; SPD, spermidine; SPM, spermine; DAP, 1,3diaminopropane.

\section{Authors' contributions}

All authors contributed equally in this paper. All authors read and approved the final manuscript.

\section{Acknowledgements}

This work was supported in part by "Pythagoras Postdoctoral Research Grant" from the Hellenic Ministry of Education (D.A.K. \& P.S.F.).

\section{References}

I. Tabor CW, Tabor H: Polyamines in microorganisms. Microbiol Rev 1985, 49:8I-99.

2. Canellakis ES, Viceps-Madore D, Kyriakidis DA, Heller JS: The regulation and function of ornithine decarboxylase and of the polyamines. In Current Topics in Cellular Regulation Volume I5. Edited by: Horecker BL, Stadtman ER. New York: Academic Press Inc; 1979:155-202.

3. Pegg AE: Polyamine metabolism and its importance in neoplastic growth and a target for chemotherapy. Cancer Res 1988, 48:759-774.

4. Marton LJ, Pegg AE: Polyamines as targets for therapeutic intervention. Annu Rev Pharmacol Toxicol 1995, 35:55-91.

5. Cohen SS: A guide to the polyamines New York: Oxford University Press; 1998.

6. Mitchell LA, Leyser A, Holtorff MS, Bates JS, Frydman B, Valasinas AL, Reddy VK, Marton LJ: Antizyme induction by polyamine analogues as a factor of cell growth inhibition. Biochem J 2002, 366:663-67I.

7. Pegg AE: Recent advances in the biochemistry of polyamines in eukaryotes. Biochem J 1986, 234:249-262.

8. Davis RH, Morris DR, Coffino P: Sequestered end products and enzyme regulation: the case of ornithine decarboxylase. Microbiol Rev 1992, 56:280-290.
9. Kyriakidis DA, Heller JS, Canellakis ES: Modulation of ornithine decarboxylase activity in Escherichia coli by positive and negative effectors. Proc Natl Acad Sci (USA) 1978, 75:4699-4703.

10. Heller JS, Fong WF, Canellakis ES: Induction of a protein inhibitor of ornithine decarboxylase by the end products of its reaction. Proc Natl Acad Sci (USA) 1976, 73:1858-1862.

II. Fujita K, Matsufuji S, Murakami Y, Hayashi S: Antizyme to ornithine decarboxylase is present in the liver of starved rats. Biochem J 1984, 2 I 8:557-562.

12. Kitani T, Fujisawa $\mathrm{H}$ : Purification and some properties of a protein inhibitor (antizyme) of ornithine decarboxylase from rat liver. J Biol Chem 1984, 259:1036-1040.

13. Hayashi SI, Canellakis ES: Ornithine decarboxylase antizymes. In International Encyclopaedia of Pharmacology and Therapeutics Volume 129. Edited by: Hayashi SI. New York: Pergamon Press Inc; 1989:47-58.

14. Glass JR, Gerner EW: Spermidine mediates degradation of ornithine decarboxylase by a non-lysosomal, ubiquitin-independent mechanism. J Cell Physiol 1987, I30: I33-14I.

15. Rosenberg-Hasson Y, Bercovich Z, Ciechanover A, Kahana C: Degradation of ornithine decarboxylase in mammalian cells is ATP dependent but ubiquitin independent. Eur J Biochem 1989 , I 85:469-474.

16. Mitchell JLA, Judd GG, Bareyal-Leyser A, Ling SY: Feedback repression of polyamine transport is mediated by antizyme in mammalian tissue-culture cells. Biochem J 1994, 299:19-22.

17. Suzuki T, Kashiwagi K, Murakami Y, Hayashi S, Igarashi K: Antizyme protects against abnormal accumulation and toxicity of polyamines in ornithine decarboxylase-overproducing cells. Proc Natl Acad Sci (USA) 1994, 9 I:8930-8934.

18. Huang SC, Panagiotidis CA, Canellakis ES: Transcriptional effects of polyamines on ribosomal proteins and on polyamine-synthesizing enzymes in Escherichia coli. Proc Natl Acad Sci (USA) 1990, 87:3464-3468.

19. Panagiotidis CA, Huang S, Canellakis ES: Post-translational and transcriptional regulation of polyamine biosynthesis in Escherichia coli . Int J Biochem 1994, 26:991-1001.

20. Morris DR, Wu WH, Applebaum D, Koffron KL: Regulatory Patterns in Putrescine Biosynthesis in Escherichia coli. Ann NY Acad Sci 1970, I 71:968-976.

21. Canellakis ES, Paterakis AA, Huang SC, Panagiotidis CA, Kyriakidis DA: Identification, cloning, and nucleotide sequencing of the ornithine decarboxylase antizyme gene of Escherichia coli. Proc Natl Acad Sci 1993, 90:7129-7I33.

22. Parkinson JS, Kofoid EC: Communication modules in bacterial signalling proteins. Annu Rev Genet I992, 26:7I-II 2.

23. Blattner FR, Plunkett G III, Bloch CA, Perna NT, Burland V, Riley M, Collado-Vides J, Glasner JD, Rode CK, Mayhew GF, Gregor J, Davis NW, Kirkpatrick HA, Goeden MA, Rose DJ, Mau B, Shao Y: The complete genome sequence of Escherichia coli K-I2. Science 1997, 277:|453-|474.

24. Chen C, Cooke PA, Rudd KE, Shanley MS: Direct submission EMBL/GenBank/DDBJ. 1994. Accession number Q06065

25. Jenkins LS, Nunn WD: Genetic and molecular characterization of the genes involved in short-chain fatty acid degradation in Escherichia coli : the ato system. J Bacteriol 1987, 169:42-52.

26. Jenkins LS, Nunn WD: Regulation of the ato operon by the atoC gene in Escherichia coli. J Bacteriol 1987, 169:2096-2102.

27. Lioliou EE, Kyriakidis DA: The role of bacterial antizyme: From an inhibitory protein to AtoC transcriptional regulator. Microb Cell Fact 2004, 3:8.

28. Lioliou EE, Mimitou EP, Grigoroudis Al, Panagiotidis $\mathrm{CH}$, Panagiotidis CA, Kyriakidis DA: Phosphorylation activity of the response regulator of the two-component signal transduction system AtoS-AtoC in E. coli. Biochim Biophys Acta 2005, I 725:257-268.

29. Oshima T, Aiba H, Masuda Y, Kanaya S, Masahito S, Wanner BL, Mori $H$, Mizuno $T$ : Transcriptome analysis of all two component regulatory system mutants of Escherichia coli K-I 2. Mol Microbiol 2002, 46:28I-291.

30. Zhou L, Lei X.-H, Bochner BR, Wanner BL: Phenotype Microarray analysis of Escherichia coli K-I 2 mutants with deletions of all two-component systems. J Bacteriol 2003, 185:4956-4972.

31. Theodorou MC, Panagiotidis CA, Panagiotidis CH, Pantazaki AA, Kyriakidis DA: Involvement of the AtoS-AtoC signal transduction system in poly(- R)-3-hydroxybutyrate biosynthesis in Escherichia coli. Biochim Biophys Acta 2006, I 760:896-906. 
32. Matsufuji S, Matsufuji T, Miyazaki Y, Murakami Y, Atkins JF, Gesteland RF, Hayashi S: Autoregulatory frameshifting in decoding mammalian ornithine decarboxylase antizyme. Cell 1995, 80:5I-60.

33. Higashi K, Yoshida K, Nishimura K, Momiyama E, Kashiwagi K, Matsufuji $S$, Shirahata $A$, Igarashi K: Structural and functional relationship among diamines in terms of inhibition of cell growth. J Biochem 2004, I 36:533-539.

34. Fogel-Petrovic M, Kramer DL, Vujcic S, Miller J, Mcmanis JS, Bergeron RJ, Porter CW: Structural basis for differential induction of spermidine/spermine $\mathbf{N}$-Acetyltransferase activity by novel spermine analogs. Molecular Pharmacology 1997, 52:69-74.

35. Janne J, Alhonen L, Pietila M, Keinanen TA: Genetic approaches to the cellular functions of polyamines in mammals. Eur J Biochem 2004, $271: 877-894$.

36. Holst CM, Frydman B, Marton LJ, Oredsson SM: Differential polyamine analogues effects in four human breast cancer cell lines. Toxicology 2006, 223:7I-8I.

37. Huang Y, Keen JC, Pledgie A, Marton LJ, Zhu T, Sukumar S, Park BH Blair B, Brenner K, Cassero RA, Davidson NE: Polyamine analogues down-regulate estrogen receptor $\alpha$ expression in human breast cancer cells. J Biol Chem 2006, 28 I: I 9055-19063.

38. Wallace HM, Fraser AV, Hughes A: A perspective of polyamine metabolism. Biochem / 2003, 376: I- I4

39. Reguera RM, Tekwani BL, Balana-Fouce R: Polyamine transport in parasites: A potential target for new antiparasitic drug development. Comp Biochem Physiol C Toxicol Pharmacol 2005, I 40:15I-164.

40. Miller JH: A Short Course in Bacterial Genetics. Cold Spring Harbor Laboratory Press: NewYork; 1992.

4I. Sambrook J, Fritsch EF, Maniatis T: Molecular cloning: a laboratory manual. Cold Spring Harbor Laboratory Press: NewYork; 1989.

42. Tsiakopoulos N, Damianakos C, Karigiannis G, Vahliotis D, Papaioannou D, Sindona G: Syntheses of crowned polyamines using isolable succinimidyl esters of $\mathbf{N}$-tritylated linear amino acids and peptides. ARKIVOC 2002, 13:79-104.

43. Athanassopoulos CM, Garnelis T, Pantazaka E, Papaioannou D: Efficient guanylation of $\mathbf{N}^{\alpha}, \mathbf{N}^{\omega}$-difunctionalized polyamines at the secondary amino functions. Tetrahedron Lett 2004, 45:88I5-88I8

44. Vassis S, Govaris I, Voyagi K, Mamos P, Papaioannou D: Simple syntheses of the polyamine alkaloid tenuilobine and analogues using selectively $\mathbf{N}$-tritylated polyamines and dicarboxylic acids as bridging elements. Tetrahedron Lett 2002, 43:2597-2600.

45. Athanassopoulos CM, Garnelis T, Vahliotis D, Papaioannou D: Efficient syntheses of 5 -aminoalkyl-I $H$-tetrazoles and of polyamines incorporating tetrazole rings. Org Lett 2005, 7:561-564.

46. Laemmli UK: Cleavage of structural proteins during the assembly of the head of bacteriophage $\mathbf{T}_{4}$. Nature (London) 1970, 227:680-685.

47. Towbin $\mathrm{H}$, Staehelin T, Gordon J: Electrophoretic transfer of proteins from acrylamide gels to nitrocellulose sheets: procedure and some applications. Proc Natl Acad Sci (USA) 1979, 76:4350-4354

48. Panagiotidis CA, Burkholder WF, Gaitanaris GA, Gragerov A, Gottesman ME, Silverstein SJ: Inhibition of DnaK autophosphorylation by heat shock proteins and polypeptide substrates. J Biol Chem 1994, 269:16643-16647.

Publish with Bio Med Central and every scientist can read your work free of charge

"BioMed Central will be the most significant development for disseminating the results of biomedical research in our lifetime. "

Sir Paul Nurse, Cancer Research UK

Your research papers will be:

- available free of charge to the entire biomedical community

- peer reviewed and published immediately upon acceptance

- cited in PubMed and archived on PubMed Central

- yours - you keep the copyright
BioMedcentral 